Manar Y Abdul-Qadir BDS, MSc (Assist Lect)

\author{
Alaa' D Al-Dawoody \\ BDS, MSc (Lect) \\ Ne'am F Agha \\ BDS, MSc (Assist Prof)
}

\section{Evaluation of Holdaway Soft Tissue Analysis for Iraqi Adults with Class I Normal Occlusion}

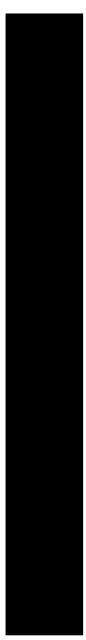

\author{
Dept of Pedod, orthod, and Prev Dentistry \\ College of Dentistry, University of Mosul
}

\begin{abstract}
Aims: To determine cephalometric standards for Iraqi adults using Holdaway soft tissue analysis. Materials and Methods: The sample comprised 60 individual (31 males and 29 females), aged 18-23 years. Ten linear and tow angular parameters were measured on lateral cephalometric radiographs, using the definitions provided by Holdaway. For each variable mean and SD were calculated, in addition independent samples t- test was performed to detect sexual dimorphism. Results:_Some differences were determined when the measurement obtained for Iraqi sample were compared to Holdaway norms. Iraqi adults showed a more obtuse $\mathrm{H}$ angle, less nose prominence, more upper lip strain, more skeletal convexity, and greater soft tissue chin thickness. In addition, a comparison between males and females revealed a significant sexual dimorphism for upper lip sulcus depth, upper lip thickness, basic upper lip thickness, and soft tissue chin thickness. Conclusions: soft tissue cephalometric norms are specific for each ethnic group. The normative data for Iraqi population should be used as a guide for diagnosis and planning of orthodontic treatment.

Key words: Soft tissue profile, Holdaway analysis.
\end{abstract}

Abdul-Qadir MY, Al-Dawoody AD, Agha NF. Evaluation of Holdaway Soft Tissue Analysis for Iraqi Adults with Class I Normal Occlusion. Al-Rafidain Dent J. 2008; 8(2): 231-237.

Received: 17/9/2007_Sent to Referees: 17/9/2007

Accepted for Publication: 2/12/2007

\section{INTRODUCTION}

The success of orthodontic treatment is frequently related to the improvement gained in the patient's facial appearance, which includes the soft tissue profile ${ }^{(1)}$, and since there is considerable variation in the soft tissue covering the face, misleading conclusions can be produced if diagnosis and treatment planning are based on dental and skeletal measurements alone (2); therefore, analysis of the soft tissue facial profile and its comparison with standard soft tissue profile measurements are necessary in all medical specialties that can change facial traits ${ }^{(3)}$.

Burstone ${ }^{(4-6)}$ was one of the first workers who developed a method of direct integument analysis and applied it in treatment planning of orthodontic cases. He stated that "Analysis of both dental and skeletal patterns alone may prove inade- quate or misleading, for marked variation exists in the thickness, length, and postural tone of soft tissue covering the dentoskeletal framework" (4).

Holdaway ${ }^{(7)}$ emphasized the importance of quantitating soft tissue features in orthodontic treatment. He noted that "Usually as we correct malocclusion, we bring about changes in appearance that are pleasing to all concerned. However, most orthodontists who have practiced for even a few years have had the unpleasant experience of finding that some patients' faces looked better before the orthodontic corrections were made".

It has become well appreciated that using the cephalometric norms developed for one population would be unsuitable in diagnosis and treatment planning of another group of people, since every race has its own dentofacial characteristics. There- 
fore orthodontists should establish specific norms for each racial or ethnic group ${ }^{(8-11)}$. With increasing acknowledgement of importance of soft tissue evaluation in treatment planning, attempts have been made to investigate the soft tissue morphology in various races and ethnic groups including African Americans ${ }^{(12,13)}$, Japanese ${ }^{(14)}$, Koreans ${ }^{(15)}$, Saudi Arabians ${ }^{(16)}$, Turkish ${ }^{(10,17)}$, Thais ${ }^{(18)}$, Spanish ${ }^{(3,19)}$, and Icelandic (20).

Taking all these points into consideration we aimed in this study to: (1) Establish Holdaway soft tissue norms for Iraqi adults who live in Mosul City; and to compare them with Holdaway norms. (2) Investigate the differences in Holdaway measurements between males and females.

MATERIALS AND METHODS

The lateral cephalometric radiographs of 60 individuals (31 males and 29 females) were included in this study. These radiographs were obtained from the Department of Pedodontics, Orthodontics and Preventive Dentistry; College of Dentistry, University of Mosul. Their age range was 18-23 years. The criteria used for sample selection included: (1) normal occlusion with bilateral Class I molar and canine relationship with normal overjet and overbite $(1-4 \mathrm{~mm}){ }^{(18)}$; (2) well aligned upper and lower dental arches with minor rotations and/or spacing (less than $1 \mathrm{~mm})^{(18)}$; (3) balanced facial profile, with competent lips, relaxed closed lip relation, and with no excessive protrusion or retrusion of the profile ${ }^{(21,22)}$; (4) no previous history of orthodontic treatment or maxillofacial surgery.

The cephalometric radiographs were taken using S.S White cephalometric machine, each subject was radiographed in the standing position with the head adjusted so that the FH plane is parallel to the floor and the midsagittal plane perpendicular to the floor. All radiographs were traced and measured by the same investigator. The following measurements were analyzed using the definitions provided by Holdaway $^{(7)}$ (Figure 1):

1. $\mathrm{H}$ angle: the angle formed between the soft tissue facial plane and the $\mathrm{H}$ line (the tangent drawn from the tip of the chin to the upper lip).

2. Soft tissue facial angle: is the down- ward and inner angle formed between FH and a line drawn from soft tissue nasion, where S-N line crosses the soft tissue profile, to soft tissue chin.

3. Nose prominence: the distance between the tip of the nose and a perpendicular line drawn to the $\mathrm{FH}$ plane from the vermilion of upper lip.

4. Upper lip sulcus depth (upper lip curl): the distance measured between the upper lip sulcus and a perpendicular line drawn from the vermilion of upper lip to the FH plane.

5. Basic upper lip thickness: the dimension measured between the drape of the upper lip and the anterior aspect of maxilla at approximately $3 \mathrm{~mm}$ below point A.

6. Upper lip thickness: the distance between labrale superius and the labial surface of maxillary incisors.

7. Upper lip strain: the difference between the basic upper lip thickness and the upper lip thickness.

8. Skeletal profile convexity: the distance between point $\mathrm{A}$ and the skeletal facial plane. The distance was denoted as positive when point $A$ was ahead of the facial plane, and as negative when point $\mathrm{A}$ was behind the plane, and as zero when point A was on the plane.

9. Soft tissue subnasale to $\mathrm{H}$ line: the measurement from subnasal point to the $\mathrm{H}$ line.

10.Lower lip to $\mathrm{H}$ line: the distance between labrale inferius and $\mathrm{H}$ line. The distance was denoted as positive when the vermilion point was ahead of the $\mathrm{H}$ line, as negative when it was behind the line, and as zero when it was located on the $\mathrm{H}$ line.

11.Inferior sulcus to the $\mathrm{H}$ line (lower lip sulcus depth): the distance measured at the point of greatest convexity between the vermilion border of the lower lip and soft tissue chin measured to the $\mathrm{H}$ line.

12.Soft tissue chin thickness: the distance between the skeletal and soft tissue facial planes at the level of Ricketts' suprapogonion.

The data were analyzed using SPSS software package (version 11.5). The minimum, maximum, mean and SD were calculated for each variable. The differences 


\section{Holdaway soft tissue analysis}

between males and females were exam- ined using independent-samples t-test.

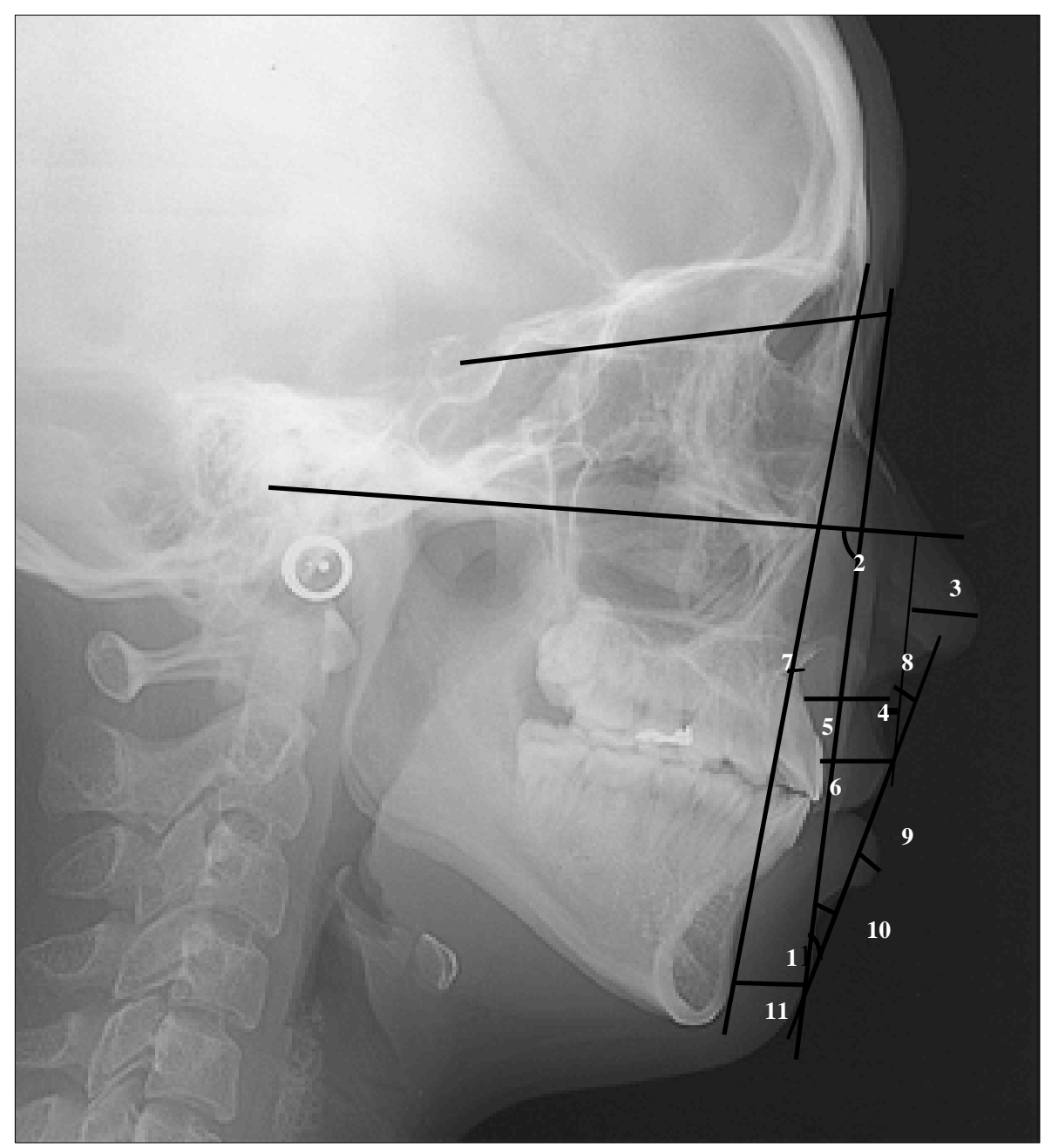

Figure (1): Holdaway soft tissue analysis. (1) H angle; (2) soft tissue facial angle; (3) nose prominence; (4) upper lip sulcus depth; (5) basic upper lip thickness; (6) upper lip thickness; (7) skeletal convexity; (8) soft tissue subnasale to H line; (9) lower lip to $\mathrm{H}$ line; (10) inferior sulcus to $\mathrm{H}$ line; (11) soft tissue chin thickness.

\section{RESULTS}

Combined descriptive statistics (minimum, maximum, means and SD) for Iraqi adults along with the values proposed by Holdaway for white normal group were presented in Table (1). Our study sample demonstrated a more obtuse $\mathrm{H}$ angle, less prominent nose; more upper lip strain; more convex skeletal profile; and thicker soft tissue chin as compared to Holdaway norms. When the means and standard deviations of measurements for males and females were compared, only 4 variables showed significant sexual dimorphism (Table 2); where males demonstrated higher values for upper lip sulcus depth, upper lip thickness, basic upper lip thickness, and chin thickness. 
Table (1): Descriptive statistics for 60 Iraqi adults.

\begin{tabular}{|c|c|c|c|c|c|}
\hline Variable & Minimum & Maximum & Mean & \pm SD & Holdaway norms \\
\hline$H$ angle & 6.00 & 20.00 & 13.13 & 3.15 & $10(7-14)$ \\
\hline $\begin{array}{l}\text { Soft tissue facial } \\
\text { angle }\end{array}$ & 84.00 & 98.00 & 91.39 & 2.98 & $91 \pm 7$ \\
\hline $\begin{array}{l}\text { Nose promi- } \\
\text { nence }\end{array}$ & 12.00 & 24.00 & 16.83 & 2.64 & $14-24$ \\
\hline $\begin{array}{l}\text { Upper lip sulcus } \\
\text { depth }\end{array}$ & .00 & 6.50 & 3.01 & 1.13 & $3(1-4)$ \\
\hline $\begin{array}{l}\text { Basic upper lip } \\
\text { thickness }\end{array}$ & 9.00 & 21.00 & 15.60 & 2.10 & $15-16$ \\
\hline $\begin{array}{l}\text { Upper lip thick- } \\
\text { ness }\end{array}$ & 9.50 & 17.00 & 13.23 & 2.05 & $13-14$ \\
\hline Upper lip strain & .00 & 5.50 & 2.41 & 1.44 & $1-2$ \\
\hline $\begin{array}{l}\text { Skeletal profile } \\
\text { convexity }\end{array}$ & -3.50 & 7.00 & 2.05 & 2.46 & $0(-3$ to 3$)$ \\
\hline $\begin{array}{c}\text { Subnasale to } \mathrm{H} \\
\text { line }\end{array}$ & .00 & 8.50 & 4.41 & 2.08 & $5 \pm 2$ \\
\hline $\begin{array}{c}\text { Lower lip to } \mathbf{H} \\
\text { line }\end{array}$ & -2.00 & 3.00 & .42 & 1.29 & $0-05$ ( -1 to 2 ) \\
\hline $\begin{array}{l}\text { Inferior sulcus } \\
\text { to } \mathrm{H} \text { line }\end{array}$ & 2.00 & 10.00 & 5.64 & 1.44 & $5 \pm 1$ \\
\hline $\begin{array}{l}\text { Soft tissue chin } \\
\text { thickness }\end{array}$ & 10.00 & 18.00 & 13.25 & 1.63 & $10-12$ \\
\hline
\end{tabular}


Table (2): Comparison of cephalometric measurements between males and females.

\begin{tabular}{|c|c|c|c|c|c|c|}
\hline Variable & Gender & No. & Mean & \pm SD & t-test & $P$ value \\
\hline$H$ angle & $\begin{array}{l}\text { male } \\
\text { female }\end{array}$ & $\begin{array}{l}31 \\
29\end{array}$ & $\begin{array}{l}12.96 \\
13.31\end{array}$ & $\begin{array}{l}3.17 \\
3.19\end{array}$ & -0.41 & 0.67 \\
\hline $\begin{array}{c}\text { Soft tissue facial } \\
\text { angle }\end{array}$ & $\begin{array}{l}\text { male } \\
\text { female }\end{array}$ & $\begin{array}{l}31 \\
29\end{array}$ & $\begin{array}{l}91.62 \\
91.13\end{array}$ & $\begin{array}{l}2.77 \\
3.22\end{array}$ & 0.63 & 0.52 \\
\hline Nose prominence & $\begin{array}{l}\text { male } \\
\text { female }\end{array}$ & $\begin{array}{l}31 \\
29\end{array}$ & $\begin{array}{l}16.75 \\
16.91\end{array}$ & $\begin{array}{l}2.56 \\
2.76\end{array}$ & -.22 & 0.82 \\
\hline $\begin{array}{l}\text { Upper lip sulcus } \\
\text { depth }\end{array}$ & $\begin{array}{l}\text { male } \\
\text { female }\end{array}$ & $\begin{array}{l}31 \\
29\end{array}$ & $\begin{array}{l}3.35 \\
2.65\end{array}$ & $\begin{array}{l}1.14 \\
1.02\end{array}$ & 2.48 & $0.016^{*}$ \\
\hline $\begin{array}{c}\text { Basic upper lip } \\
\text { thickness }\end{array}$ & $\begin{array}{l}\text { male } \\
\text { female }\end{array}$ & $\begin{array}{l}31 \\
29\end{array}$ & $\begin{array}{l}16.51 \\
14.62 \\
\end{array}$ & $\begin{array}{l}1.89 \\
1.89\end{array}$ & 3.86 & $0.000 * *$ \\
\hline $\begin{array}{l}\text { Upper lip thick- } \\
\text { ness }\end{array}$ & $\begin{array}{l}\text { male } \\
\text { female }\end{array}$ & $\begin{array}{l}31 \\
29\end{array}$ & $\begin{array}{l}14.51 \\
11.86\end{array}$ & $\begin{array}{l}1.57 \\
1.58\end{array}$ & 6.51 & $0.000 * *$ \\
\hline Upper lip strain & $\begin{array}{l}\text { male } \\
\text { female }\end{array}$ & $\begin{array}{l}31 \\
29\end{array}$ & $\begin{array}{l}2.06 \\
2.79\end{array}$ & $\begin{array}{l}1.34 \\
1.47\end{array}$ & -2.00 & 0.050 \\
\hline $\begin{array}{l}\text { Skeletal profile } \\
\text { convexity }\end{array}$ & $\begin{array}{l}\text { male } \\
\text { female }\end{array}$ & $\begin{array}{l}31 \\
29\end{array}$ & $\begin{array}{l}1.70 \\
2.43\end{array}$ & $\begin{array}{l}2.69 \\
2.17\end{array}$ & -1.14 & 0.25 \\
\hline $\begin{array}{c}\text { Subnasale to } \mathrm{H} \\
\text { line }\end{array}$ & $\begin{array}{l}\text { male } \\
\text { female }\end{array}$ & $\begin{array}{l}31 \\
29\end{array}$ & $\begin{array}{l}4.74 \\
4.06\end{array}$ & $\begin{array}{l}2.06 \\
2.08\end{array}$ & 1.25 & 0.21 \\
\hline Lower lip to $\mathbf{H}$ line & $\begin{array}{l}\text { male } \\
\text { female }\end{array}$ & $\begin{array}{l}31 \\
29\end{array}$ & $\begin{array}{l}.67 \\
.15\end{array}$ & $\begin{array}{l}1.24 \\
1.31\end{array}$ & 1.58 & 0.11 \\
\hline $\begin{array}{c}\text { Inferior sulcus to } \\
\text { H line }\end{array}$ & $\begin{array}{l}\text { male } \\
\text { female }\end{array}$ & $\begin{array}{l}31 \\
29\end{array}$ & $\begin{array}{l}5.90 \\
5.36\end{array}$ & $\begin{array}{l}1.64 \\
1.16\end{array}$ & 1.46 & 0.14 \\
\hline $\begin{array}{l}\text { Soft tissue chin } \\
\text { thickness }\end{array}$ & $\begin{array}{l}\text { male } \\
\text { female }\end{array}$ & $\begin{array}{l}31 \\
29\end{array}$ & $\begin{array}{l}14.01 \\
12.43\end{array}$ & $\begin{array}{l}1.62 \\
1.20\end{array}$ & 4.26 & $0.000 * *$ \\
\hline
\end{tabular}

* significant at $p<0.05, * *$ highly significant at $p<0.001 . \mathrm{df}=58$.

\section{DISCUSSION}

In evaluating Holdaway analysis in Iraqi adults sample we determined some differences regarding certain variables between Iraqi adults and Holdaway white group. Our results showed a higher mean value for $\mathrm{H}$ angle $\left(13.13^{\circ}\right)$ than the ideal value proposed by Holdaway $\left(10^{\circ}\right)$ and this is justified by the higher degree of skeletal convexity $(2.05 \pm 2.46 \mathrm{~mm})$ that was exhibited by our sample. According to Holdaway ${ }^{(7)}$ as the skeletal convexity increases $\mathrm{H}$ angle must also increase if a harmonious drape of soft tissue is to be realized in varying degrees of profile convexity. This finding is in agreement with the results reported for other ethnic groups including Turkish ${ }^{(11,17)}\left(13.75 \pm 3.01^{\circ}\right)$, Japanese $^{(14)}\left(15.51 \pm 4.28^{\circ}\right)$, and Koreans ${ }^{(15)}$ $\left(17.4+2.87^{\circ}\right)$.

The more convex skeletal profile reported in the current study is in line with the results obtained by other researchers who investigated the craniofacial morphology in non Caucasian adults with well balanced faces ${ }^{(14,16,23)}$. It is also clear that the difference between upper lip thickness and basic upper lip thickness reveals that our sample had more upper lip strain $(2.41 \pm 1.44)$ when compared to Holdaway norms ${ }^{(7)}$; this may be attributed to increased labial inclination of upper incisors 
in Iraqi subjects, as has been reported earlier for Iraqis ${ }^{(24)}$, which stretches the vermilion portion of the upper lip upon closure. A larger upper lip strain was also reported for Japanese ${ }^{(14)}(2.57 \pm 2.73)$, and Turkish adults ${ }^{(17)}(2.68+2.39)$.

According to Holdaway ${ }^{(7)}$, the contour in the inferior sulcus $(5 \pm 1 \mathrm{~mm})$ should fall into harmonious line with superior sulcus form ( $2-4 \mathrm{~mm})$. The mean values obtained for upper and lower lip sulcus depths in the present study, shows a definite curl of the upper lip, and lower lip form and sulcus that is harmonious with those of upper lip. Our results also showed less nose prominence and more soft tissue chin thickness than Holdaway norms ${ }^{(7)}$, this can be attributed to the ethnic variation.

A comparison between males and females disclosed that males had significantly higher upper lip sulcus depth, greater upper lip thickness and soft tissue chin thickness. Similar findings were reported by Basciftci et al., ${ }^{(17)}$, however the difference regarding upper lip sulcus depth was statistically insignificant. Genecov et al., ${ }^{(25)}$, who measured upper lip sulcus depth in relation to subnasale vertical line, also reported larger value in young adult males as compared to females.

When the results of the current study were compared with those performed on other populations, similar findings were reported regarding the insignificant difference between men and women for $\mathrm{H}$ angle $(11,15,17,23)$. On the other hand, our findings regarding soft tissue facial angle disagree with those reported by Hashim and $\mathrm{Al} \mathrm{Ba-}$ racati ${ }^{(16)}$ who showed a significantly higher value in females than males. In addition, the present investigation showed no sexual dimorphism in nose prominence which agrees with the results obtained by Scavone et al., ${ }^{(26)}$, but disagrees with the findings reported for Turkish ${ }^{(17,27)}$ and Saudi ${ }^{(16)}$ adults.

On analyzing the position of soft tissue subnasale, lower lip, and inferior sulcus in relation to $\mathrm{H}$ line; it was observed that the values were similar for both sexes. These findings are in line with those reported by Sushner ${ }^{(12)}$ for AfricanAmericans. Other researchers ${ }^{(10,11,15)}$, who have only included lower lip distance in relation to $\mathrm{H}$ line in their cephalometric evaluation also showed insignificant difference between sexes.

\section{CONCLUSIONS}

This study focused on evaluating soft tissue profile of Iraqi adults according to Holdaway analysis. The results revealed that some measurements were different from those proposed by Holdaway, including; $\mathrm{H}$ angle, nose prominence, upper lip strain, skeletal convexity, and soft tissue chin thickness. These differences disclose the importance of using normative data established for Iraqi individuals in formulating orthodontic diagnosis and treatment plan. When the differences between the sexes were explored, only four variables showed statistically significant difference. Men possessed more upper lip curvature, greater upper lip

and basic upper lip thickness, and thicker soft tissue chins.

\section{REFERENCES}

1. Bass NM. Measurement of the profile angle and the esthetic analysis of the facial profile. J Orthod. 2003; 30(1): 3-9.

2. Legan HL, Burstone CJ. Soft tissue cephalometric analysis for orthognathic surgery. J Oral Surg. 1980; 38: 744-751.

3. Fernandez-Riveiro P, Smyth-Chamosa E, Suarez-Quintanilla D, Suarez-Cunqueiro M. Angular photogrammetric analysis of the soft tissue facial profile. Eur J Orthod. 2003; 25: 393-399.

4. Burstone CJ. The integumental profile. Am J Orthod. 1955; 44(1): 1-25.

5. Burstone CJ. Integumental contour and extension patterns. Angle Orthod. 1959; 29(2): 93-104.

6. Burstone CJ. Lip posture and its significance in treatment planning. Am J Orthod. 1967; 53(4): 262-284.

7. Holdaway RA. A soft tissue cephalometric analysis and its use in orthodontic treatment planning. Part I. Am J Orthod. 1983; 84(1): 1-28.

8. Richardson ER. Racial differences in dimensional traits of the human face. Angle Orthod. 1980; 50(4): 301-311. 
9. Hamdan AM, Rock WP. Cephalometric norms in an Arab population. J Orthod. 2001; 28(4): 297-300.

10.Erbay EF, Canikliglu CM, Erbay SK. Soft tissue profile in Anatolian Turkish adults: Part I. evaluation of horizontal lip position using different soft tissue analyses. Am J Orthod Dentofacial Orthop. 2002; 121(1): 57-64.

11.Basciftci FA, Uysal T, Buyukerkmen A. Craniofacial structure of Anatolian Turkish adults with normal occlusions and well balanced faces. Am J Orthod Dentofacial Orthop. 2004; 125(3): 366-372.

12.Sushner NI. A photographic study of the soft tissue profile of the Negro population. Am J Orthod. 1977; 72(4): 373-385.

13. Sutter RE, Turley PK. Soft tissue evaluation of contemporary Caucasian and African American female facial profile. Angle Orthod. 1998; 68(6): 487-496.

14. Alcade RE, Jinno T, Orsini MG, Sasaki A, Sugiyama RM, Matsumura T. Soft tissue cephalometric norms in Japanese adults. Am J Orthod Dentofacial Orthop. 2000; 118(1): 84-89.

15.Hwang HS, Kim WS, McNamara JA Jr. Ethnic differences in the soft tissue profile of Korean and European-American adults with normal occlusions and well balanced faces. Angle Orhod. 2002; 72(1): 72-80.

16. Hashim HA, Al Barakati SF. Cephalometric soft tissue profile analysis between two different ethnic groups: A comparative study. J Contemp Dent Prac. 2003; 4(2): 60-73.

17.Basciftci FA, Uysal T, Buyukerkmen A. Determination of Holdaway soft tissue norms in Anatolian Turkish adults. Am J Orthod Dentofacial Orthop. 2003; 123(4): 395-400.

18.Ruksujarit T, Ratanya C, Godfrey K, Deesamur S. Lateral cephalometric norms for 12-14 years Thai girls and boys in
Khon Kaen with an acceptable profile. Khon Kaen Univ Dent J. 2001; 6: 76-83.

19. Ferandez-Riveiro P, Suarez-Quintanilla D, Smyth-Chamosa E, Suarez-Cunqueiro M. Linear photogrammetric analysis of the soft tissue facial profile. Am $J$ Orthod Dentofacial Orthop. 2002; 122(1): 59-66.

20.Johannsdottir B, Thordarson A, Magnusson TE. Craniofacial skeletal and soft tissue morphology in Icelandic adults. Europ J Orthod. 2004; 26(3): 245-250.

21. Canut J, Minana PM, Plasencia E. Facial differences between Northern and Southern European children. Angle Orthod. 1987; 57(1): 63-69.

22.Akgul AA, Toygar TU. Natural craniofacial changes in the third decade of life: A longitudinal study. Am J Orthod Dentofacial Orthop. 2002; 122(5):512-522.

23.El Faituri H, Rani MS. Cephalometric norms for Libyan population. Arab Dent J. 1994; 1: 35-47.

24.Al-Sayagh NM. Dentoskeletal analysis and facial types of Iraqi adults in Mosul City with Class one normal occlusion (a lateral radiographic cephalometric study). MSc. Thesis. College of Dentistry. University of Mosul. 1999.

25.Genecov JS, Sinclair PM, Dechow PC. Development of the nose and soft tissue profile. Angle Orthod. 1990; 60(3): 191198.

26.Scavone HJr, Trevisan HJr, Garib DG, Ferreira FV. Facial profile evaluation in Japanese-Brazilian adults with normal occlusion and well balanced faces. Am J Orthod Dentofacial Orthop. 2006; 129(60): 721.e1-721.e5.

27. Gulsen A, Okay C, Belma IA, Uner O, Yavuzer R. The relationship between craniofacial structures and the nose in Anatolian Turkish adults: A cephalometric evaluation. Am J Orthod Dentofacial Orthop. 2006; 130(2): 131.e15-131.e25. 